Turkish Journal of Thoracic and Cardiovascular Surgery 2019;27(4):512

http://dx.doi.org/doi: 10.5606/tgkdc.dergisi.2019.01908

Editorial Comment / Editoryal Yorum

\title{
First but not last: Forearm!
}

\author{
Illk ama son değil: Önkol!
}

İsmet Tanzer Çalkavur (D)

Department of Cardiovascular Surgery, Ege University School of Medicine, Izmir, Turkey

Improved survival and higher diabetes rates in patients with end-stage renal disease have rendered vascular access an increasingly challenging issue. Autogenous conduits are recommended by the current guidelines for vascular access over other options. ${ }^{[1]}$ In case of failing radiocephalic or brachiocephalic arteriovenous fistulas, humeral basilic vein transposition should be preferred over arteriovenous grafts. To preserve the proximal vasculature, assessment of forearm basilic vein transposition may reveal a promising option for arteriovenous fistulas.

I would like to congratulate the authors for their efforts on autogenous vascular access. Unfortunately, studies on basilic vein transposition in the forearm are very limited and mostly comprise of case series with a small number of patients. As mentioned by the authors, the retrospective design, lack of a control group, and small smaple size are the main limitations of this study. ${ }^{[2]}$ In contrast to other series published, in cases where the basilic vein was too short, the authors used an extension with the saphenous vein. However, there would be a risk for a puncture to disrupt the sapheno- basilic anastomosis which poses a risk for catastrophic bleeding and loss of venous access, as the saphenobasilic anastomosis would be on the fistula trace for puncture for dialysis access. Therefore, a forearm loop graft with in situ basilic vein may be a more preferable option for short forearm basilic veins.

\section{Declaration of conflicting interests}

The authors declared no conflicts of interest with respect to the authorship and/or publication of this article.

\section{Funding}

The authors received no financial support for the research and/or authorship of this article.

\section{REFERENCES}

1. Schmidli J, Widmer MK, Basile C, de Donato G, Gallieni M, Gibbons CP, et al. Editor's Choice - Vascular Access: 2018 Clinical Practice Guidelines of the European Society for Vascular Surgery (ESVS). Eur J Vasc Endovasc Surg 2018;55:757-818.

2. Uzun HA, Çiçek ÖF, Seren M. Transposition of basilic vein in forearm for arteriovenous fistula creation: Our mid-term results. Turk Gogus Kalp Dama 2019;27:508-11.

Received: October 14, 2019 Accepted: October 16, 2019 Published online: October 23, 2019

Correspondence: İsmet Tanzer Çalkavur, MD. Ege Üniversitesi Tıp Fakültesi Kalp ve Damar Cerrahisi Anabilim Dalı, 35100 Bornova, İzmir, Turkey.

Tel: +90 532 - 3622953 e-mail: tanzercalkavur@gmail.com 